\title{
Pengetahuan Ibu tentang Pertumbuhan Berhubungan dengan Status Gizi Anak Usia 0-59 Bulan di Wilayah Kerja Puskesmas Banguntapan I Bantul, Yogyakarta
}

\author{
Rikardus Nendi Irwanto ${ }^{1}$, Sulistiyawati ${ }^{2}$, Prastiwi Putri Basuki ${ }^{3}$ \\ 1,3Program Studi IImu Keperawatan Sekolah Tinggi IImu Kesehatan Wira Husada Yogyakarta \\ Jalan Babarsari, Glendongan, Daerah Istimewa Yogyakarta \\ 2 Universitas Alma Ata Yogyakarta \\ Jalan Ringroad Barat Daya No 1 Tamantirto, Kasihan, Bantul, Yogyakarta \\ Email: jellistya@yahoo.com
}

\begin{abstract}
Abstrak
Salah satu tujuan lain dari MDGs adalah untuk memberantas kemiskinan dan kelaparan. Semakin tinggi kemiskinan dan kelaparan suatu negara akan berdampak pada kesehatan, kesejahteraan dan kekurangan gizi, terutama pada balita. Kebutuhan Nutrisi adalah perhatian utama yang harus diperhatikan dalam pertumbuhan mereka. Nutrisi dapat menentukan tingkat kesehatan anak-anak. Pertumbuhan yang baik tidak hanya pertumbuhan fisik tetapi juga perkembangan mental dan intelektual yang juga diharapkan berkembang dengan baik. Oleh karena itu menjadi pertumbuhan lazim. Tujuan dari penelitian adalah untuk mengetahui hubungan antara pengetahuan ibu tentang pertumbuhan dan status gizi anak-anak usia 0-59 bulan di wilayah kerja Puskesmas Banguntapan I Bantul. Metode ini merupakan penelitian deskriptif analitik menggunakan desain cross sectional dan analisis penelitian data spearman rho. Pengambilan sampel menggunakan cluster sampling dengan undian. Hasil penelitian menunjukkan bahwa pengetahuan ibu tentang pertumbuhan dalam kategori baik 55,1\% dan kategori kurang 3,4\%. Sementara itu, status gizi anak-anak pada usia 0-59 bulan adalah dalam kategori baik 70,8\% dan kategori sangat tipis 3,4\%. Kesimpulannya, ada hubungan antara pengetahuan ibu tentang pertumbuhan dan status gizi anak-anak usia 0-59 bulan di wilayah kerja Puskesmas Banguntapan I Bantul ( $p$-value=0,000).
\end{abstract}

Kata Kunci: pengetahuan, pertumbuhan, status gizi

\section{Mother's Knowledge on Growth is Related with Children's Nutrition Status Aged 0-59 Months in Working Area of Puskesmas Banguntapan I Bantul, Yogyakarta}

\begin{abstract}
One of the stated goals of MDGs is to eradicate extreme poverty and hunger. The higher the poverty and hunger of a country will have an impact on the health, welfare and food consumption of malnourished people, especially in toddlers. Nutrition necessity is main concern that must be considered in their growth. Nutrition status can determine the level of children's health. Good growth is not only physical growth but also their mental and intellectual development that is also expected to develop well. Therefore it becomes prevalent growth. The purpose of study was to know the relationship between mother's knowledge on growth and children's nutrient status aged 0-59 months in working area of Puskesmas Banguntapan I Bantul. The method was descriptive analytical research using cross sectional design and data research analysis of spearman rho. The sample collection was cluster sampling with lottery. Results showed that mother's knowledge on growth was in good category $55.1 \%$ and less category 3.4\%. Meanwhile, the nutrition status of children at age 0-59 months was in good category $70.8 \%$ and very thin category 3.4\%. In conclusion, there was a relationship between mother's knowledge on growth and children's nutrition status aged 0-59 months in working area of Puskesmas Banguntapan I Bantul ( $p$-value=0,000).
\end{abstract}

Keywords: knowledge, growth, nutrient status

Info Artikel:

Artikel dikirim pada 9 Januari 2016

Artikel diterima pada 9 Februari 2016

DOI : http://dx.doi.org/10.21927/jnki.2016.4(1).19-24 


\section{PENDAHULUAN}

Millennium Development Goals (MDGs) mempunyai delapan butir tujuan dimana dari setiap tujuannya terkandung target-target yang spesifik dan terukur yang akan dicapai sampai tahun 2015. Salah satu dari tujuan yang telah ditetapkan MDGs yaitu memberantas kemiskinan dan kelaparan ekstrim. Semakin tinggi angka kemiskinan dan kelaparan suatu negara akan berdampak pada kesehatan, kesejahteraan serta konsumsi makanan masyarakat yang kurang gizi(1).

Secara global ada peningkatan status gizi anak-anak. Persentase balita dengan gizi kurang diperkirakan telah menurun dari $25 \%$ pada tahun 1990 menjadi $16 \%$ pada tahun 2010 . Persentase stunting pada anak balita mengalami penurunan secara global dari $40 \%$ menjadi $12 \%$ selama periode yang sama, di Asia, jumlah anak-anak yang terhambat pertumbuhannya diperkirakan pada tahun 1990 (190 juta) dan tahun 2010 (100 juta), namun di Afrika jumlah anak stunting (pendek) di proyeksi meningkat dari 45 juta pada tahun 1990 menjadi 60 juta pada tahun 2010. Meskipun secara keseluruhan, sekitar 104 juta anak balita diperkirakan kekurangan gizi pada tahun 2010. Saat ini Indonesia menempati peringkat kelima, negara dengan balita gizi buruk se-Asia(2).

Masalah gizi buruk merupakan masalah kesehatan utama masyarakat Indonesia. Berdasarkan hasil riset kesehatan dasar (RISKESDAS) tahun 2010 menunjukkan bahwa prevalensi balita yang kurang gizi secara Nasional sebesar $17,9 \%$ di antaranya $4,9 \%$ gizi buruk. Prevalensi balita gizi kurang menurut provinsi yang tertinggi adalah Provinsi Nusa Tenggara Barat (NTB) yaitu 30,5\%(3).

Persentase status gizi masyarakat di Kabupaten Bantul pada tahun 2012 yaitu masih ada balita yang kekurangan energi protein (KEP) sebesar $11,31 \%$ meskipun sudah berada dibawah target Nasional pada tahun 2015 yaitu 15\% (MDGs). Kasus gizi buruk balita tertinggi terjadi di Wilayah Kecamatan Banguntapan sebanyak 28 kasus terdiri dari 10 lakilaki dan 18 perempuan(4).

Gizi merupakan salah satu faktor penting yang menentukan tingkat kesehatan dan kesejahteraan manusia. Gizi seseorang dikatakan baik apabila terdapat keseimbangan dan keserasian antara pertumbuhan fisik dan perkembangan mental orang tersebut(5).

Pertumbuhan dan perkembangan pada dasarnya merupakan dua peristiwa yang berlainan, akan tetapi keduanya saling berkaitan. Pertumbuhan merupakan masalah perubahan dalam ukuran besar, jumlah, ukuran atau dimensi tingkat sel, organ maupun individu yang bisa diukur dengan ukuran berat dan ukuran panjang(6).

Pertumbuhan dapat dibagi kedalam dua jenis yaitu pertumbuhan linear dan pertumbuhan massa jaringan. Proses pertumbuhan yang tidak optimal dipengaruhi oleh faktor internal dan faktor eksternal(7).

Demi mencapai pertumbuhan anak yang optimal sesuai tahapan usia secara normal anak memerlukan asupan nutrisi yang adekuat. Makanan yang dikonsumsi harus mengandung zat gizi, yaitu karbohidrat, protein, lemak, vitamin, mineral dan air(8).

Pengetahuan merupakan hasil dari tahu, dimana setelah seseorang melakukan penginderaan terhadap suatu objek tertentu(9).

Rendahnya pengetahuan orang tua, khususnya ibu dalam mengasuh anak merupakan faktor yang paling mendasar dalam mewariskan status kesehatan bagi anak-anak mereka. Orang tua yang sehat dan gizinya baik akan mewariskan kesehatan yang baik pula kepada anaknya. Pendidikan, lingkungan, sosial budaya, pengalaman, usia serta status ekonomi juga mempengaruhi pengetahuan seorang ibu dalam memberikan asupan gizi yang seimbang dan tepat kepada anak(10).

Kebutuhan gizi balita merupakan hal utama yang perlu diperhatikan dalam pertumbuhan buah hati. Masa-masa tumbuh kembangnya akan sangat berpengaruh dengan asupan gizi yang ibu berikan. Dalam pertumbuhan yang baik tidak hanya sebatas fisik, tetapi mental dan intelektualitasnya juga diharapkan dapat berkembang dengan baik, sehingga menjadi proses pertumbuhan dengan tumbuh kembang yang lazim. Dalam pertumbuhan balita 5 tahun pertamanya sangat penting diberikan asupan gizi yang tepat dan seimbang, karena di masa inilah yang dapat menentukan dan mempengaruhi perkembangan di tahap selanjutnya sehingga anak dapat tumbuh secara optimal dan sehat. Masa balita umur 3 tahun, merupakan masa-masa pertumbuhan dan perkembangan yang sangat penting untuk mempengaruhi sel-sel otak dalam membangun jaringan saraf agar lebih kompleks(11).

Asupan gizi balita yang tepat adalah makan yang sehat dan bervariasi. Berikan komposisi makanan yang seimbang pada setiap kandungan gizi masing-masing makanannya seperti $56-67 \%$ karbohidrat, $20-30 \%$ lemak, dan $13-15 \%$ protein. Hal ini agar memenuhi gizi balita dalam perkembangan kecerdasan dan pertumbuhan fisiknya secara optimal(11).

Gizi sangat berpengaruh dalam membantu proses pertumbuhan balita. Balita yang terpenuhi 
dengan baik asupan gizi cenderung akan mengalami peningkatan tinggi badan dan berat badan lebih baik dibandingkan balita yang kekurangan gizi.

Berdasarkan hasil studi pendahuluan pada bulan Desember tahun 2012 didapatkan hasil bahwa data mengenai status gizi balita di Wilayah Kerja Puskesmas Banguntapan I Bantul Yogyakarta menunjukkan jumlah balita yang ada di Puskesmas pada bulan Oktober sebanyak 2.538 balita. Balita yang berada di bawah garis merah (BGM) sebanyak 17 orang $(1,7 \%)$ yang terdiri dari laki-laki 10 orang dan perempuan 7 orang. Hasil wawancara yang dilakukan dengan petugas kesehatan gizi didapatkan hasil bahwa program penyuluhan, pemeriksaan, memotivasi ibu balita, dan konsultasi gizi merupakan upaya yang sudah dilakukan oleh Puskesmas dalam penanggulangan masalah gizi dari Puskesmas Banguntapan I Bantul dengan target yang diingikan Puskesmas untuk status gizi buruk adalah $2 \%$. Masalah gizi disebabkan penyakit penyerta, pola asuh orang tua, masalah ekonomi, serta kurangnya pemahaman orang tua tentang asupan gizi.

Tujuan penelitian untuk menganalisis lebih lanjut hubungan pengetahuan ibu tentang pertumbuhan dengan status gizi anak usia 0-59 bulan di Wilayah Kerja Puskesmas Banguntapan I Bantul Yogyakarta.

\section{BAHAN DAN METODE}

Penelitian ini merupakan penelitian deskriptif analitik dengan pendekatan cross sectional. Penelitian ini dirancang untuk mempelajari dinamika korelasi dengan cara pendekatan observasi atau pengumpulan data sekaligus pada suatu saat. Penelitian ini untuk mencari hubungan antara pengetahuan ibu tentang pertumbuhan dengan status gizi anak usia 0-59 bulan di Desa Jambidan Wilayah Kerja Puskesmas Banguntapan I Bantul Yogyakarta sebanyak 89 responden. Metode pemgambilan sampel dalam penelitian ini menggunakan teknik cluster sampling dengan cara undian. Teknik pengumpulan data yang digunakan adalah wawancara menggunakan kuesioner atau daftar pertanyaan yang disusun secara tertulis. Pelaksanaan uji validitas dan reliabilitas data dilaksanakan pada tanggal 09 April 2013 di Desa Baturetno Wilayah kerja Puskesmas Banguntapan 1 Bantul Yogyakarta. Desa Baturetno memiliki karakteristik yang hampir sama dengan tempat penelitian Desa Jambidan. Desa Baturetno merupakan Wilayah dengan prevalensi balita BGM terbanyak ketiga dengan jumlah balita pada bulan Oktober tahun 2012 sebanyak 939 balita. Jumlah responden yang dijadikan sampel sebanyak 20 orang. Hasil uji uji validitas dan reliabilitas data pengetahuan ibu tentang pertumbuhan balita dengan 20 item pertanyaan didapatkan hasil $r$ tabel $=0,444$ dan alpha cronbach sebesar 0,939 , maka kuesioner tersebut dinyatakan valid dan reliabel sehingga dapat digunakan untuk mengumpulkan data dalam penelitian.

\section{HASIL DAN BAHASAN}

\section{Karakteristik Responden}

Berdasarkan hasil penelitian yang telah dilakukan terhadap 89 reponden. Karakteristik usia, pendidikan, pekerjaan, paritas, umur balita, dan jenis kelamin dapat dilihat pada Tabel 1.

Tabel 1. Distribusi Frekuensi Karakteristik Responden di Desa Jambidan Wilayah Kerja Puskesmas Banguntapan I Bantul Yogyakarta, Juli 2013

\begin{tabular}{lcc}
\hline \multicolumn{1}{c}{ Karakteristik } & $\mathbf{f}$ & $\%$ \\
\hline $\begin{array}{l}\text { Usia Ibu (Tahun) } \\
<20\end{array}$ & 0 & 0,0 \\
$20-35$ & 70 & 83,15 \\
$\quad>35$ & 15 & 16,85 \\
Pendidikan & & \\
$\quad$ Tidak Tamat SD & 1 & 1,1 \\
SD & 6 & 6,7 \\
SMP & 38 & 42,7 \\
SMA & 44 & 49,4 \\
Pekerjaan & & \\
IRT & 76 & 85,4 \\
Swasta & 13 & 14,6 \\
Paritas & & \\
1 & 30 & 33,7 \\
2 & 51 & 57,3 \\
3 & 6 & 6,7 \\
4 & 2 & 2,2 \\
Jenis Kelamin & & \\
Laki-Laki & 52 & 58,4 \\
Perempuan & 37 & 41,6 \\
Umur Balita (Tahun) & & \\
0-1 & 25 & 28,09 \\
$>1-3$ & 42 & 47,19 \\
>3-5 & 22 & 24,72 \\
Total & 89 & 100,0 \\
\hline
\end{tabular}

Sumber: Data Primer Tahun 2013

Berdasarkan Tabel 1 responden dalam penelitian ini sebagian besar berusia 20-35 tahun sebanyak 74 responden $(83,15 \%)$, sebagian kecil responden berusia $>35$ tahun sebanyak 15 responden $(16,85 \%)$. Berdasarkan tingkat pendidikan, responden dengan pendidikan SMA sebanyak 44 responden $(49,4 \%)$, sebagian responden yang tidak tamat SD sebanyak 1 responden $(1,1 \%)$. 
Sebagian besar ibu tidak bekerja (IRT) sebanyak 76 responden $(85,4 \%)$, sebanyak 13 responden $(14,6 \%)$ pekerja swasta. Sebagian besar paritas ibu 2 anak sebanyak 51 responden (57,3\%), sebagian kecil paritas ibu 4 anak sebanyak 2 responden $(2,2 \%)$. Menurut karakteristik jenis kelamin sebagian besar jenis kelamin balita adalah laki-laki sebanyak 52 responden $(58,4 \%)$ dan perempuan sebanyak 37 responden $(41,6 \%)$. Berdasarkan umur balita sebagian besar umur balita adalah 1-3 tahun sebanyak 42 responden $(47,19 \%)$.

\section{Pengetahuan Ibu tentang Pertumbuhan}

Distribusi frekuensi pengetahuan ibu tentang pertumbuhan di Desa Jambidan wilayah kerja Puskesmas Banguntapan I Bantul Yogyakarta dibagi atas baik, cukup, dan kurang.

Tabel 2. Distribusi Frekuensi Pengetahuan Ibu tentang Pertumbuhan di Desa Jambidan Wilayah Kerja Puskesmas Banguntapan I Bantul Yogyakarta, Juli 2013

\begin{tabular}{lcc}
\hline $\begin{array}{c}\text { Pengetahuan Ibu tentang } \\
\text { Pertumbuhan }\end{array}$ & f & \% \\
\hline Baik & 49 & 55,1 \\
Cukup & 37 & 41,6 \\
Kurang & 3 & 3,4 \\
Jumlah & 89 & 100,0 \\
\hline
\end{tabular}

Sumber: Data Primer Tahun 2013

Berdasarkan Tabel 2 sebagian besar responden mempunyai pengetahuan yang baik tentang pertumbuhan yaitu sebanyak 49 responden $(55,1 \%)$, dan sebanyak 3 responden $(3,4 \%)$ pengetahuannya kurang. Hal ini di karenakan latar belakang pendidikan formalnya yang paling banyak adalah SMA (49,9\%). Pengetahuan merupakan tingkat pemahaman ibu tentang pertumbuhan anak, perawatan, pemberian makanan, pemilihan dan pengolahan makanan anak balita(9). Pengetahuan merupakan hasil dari tahu, dimana setelah seseorang melakukan penginderaan terhadap suatu objek tertentu. Pengetahuan atau informasi yang diperoleh baik dari pendidikan formal maupun non formal dapat memberikan pengaruh jangka pendek, sehingga dapat menghasilkan perubahan atau peningkatan pengetahuan. Kondisi tersebut juga didukung semakin banyaknya informasi yang diakses ibu-ibu di Desa Jambidan melalaui berbagai media yang sudah moderen meliputi televisi, radio, surat kabar, majalah, tabloit dapat menambah wawasan pengetahuan ibu(10).

Hasil penelitian keduanya menunjukkan tingkat pengetahuan ibu tentang gizi sangat tinggi, rendahnya pengetahuan orang tua, khususnya ibu dalam mengasuh anak merupakan faktor yang paling mendasar dalam mewariskan status kesehatan bagi anak-anak mereka(12).

Masalah pengetahuan gizi tidak selalu berkaitan dengan pengetahuan ibu, tetapi bisa karena faktor lain, bisa karena masalah kekurangan pagan tingkat rumah tangga, peningkatan status gizi memerlukan kebijakan yang menjamin setiap anggota keluarga atau masyarakat untuk memperoleh makan yang cukup jumlah dan mutunya(13).

\section{Status Gizi Anak Usia 0-59 Bulan}

Distribusi frekuensi status gizi anak usia 0-59 bulan di Desa Jambidan wilayah kerja Puskesmas Banguntapan I Bantul Yogyakarta dibagi atas: Normal, gemuk, kurus, dan sangat kurus.

Tabel 3. Distribusi Frekuensi Status Gizi Anak Usia 0-59 Bulan di Desa Jambidan Wilayah Kerja Puskesmas Banguntapan I Bantul Yogyakarta, Juli 2013

\begin{tabular}{lcc}
\hline Status Gizi & f & $\%$ \\
\hline Normal & 67 & 75,3 \\
Gemuk & 16 & 18,0 \\
Kurus & 3 & 3,4 \\
Sangat Kurus & 3 & 3,4 \\
Jumlah & 89 & 100,0 \\
\hline
\end{tabular}

Sumber: Data Primer Tahun 2013

Berdasarkan Tabel 3 Sebagian besar status gizi balitanya baik yaitu sebanyak 63 responden $(70,8 \%)$. Hal ini menunjukkan rata-rata status gizi anak usia 0-59 bulan di Desa Jambidan Wilayah Kerja Puskesmas Banguntapan I Bantul Yogyakarta termasuk dalam kategori normal.

Menurut analisis anak usia 0-59 bulan merupakan masa-masa dimana pertumbuhan dan perkembangan anak sangat pesat, di usia seperti ini anak-anak membutuhkan zat-zat gizi yang banyak dengan kualitas yang tinggi. Usia 0-59 bulan merupakan usia yang rentan terkena masalah kesehatan terutama masalah gizi, agar hal ini tidak terjadi dibutuhkan peran aktif dari orang tua dalam memenuhi kebutuhan anak(11).

Masalah gizi disebabkan karena penyakit penyerta, pola asuh orang tua, masalah ekonomi, serta kurangnya pemahaman orang tua tentang asupan gizi. Asupan gizi balita yang tepat adalah makan yang sehat dan bervariasi, memberikan komposisi makanan yang seimbang pada setiap kandungan gizi masing-masing makanannya seperti 56-67\% karbohidrat, $20-30 \%$ lemak, dan $13-15 \%$ protein. Hal ini agar memenuhi gizi balita dalam perkembangan kecerdasan dan pertumbuhan fisiknya 
secara optimal. Hasil penelitiannya menunjukkan status gizi anak usia balita baik(13).

Gizi merupakan salah satu penentu kualitas sumber daya manusia. Akibat kekurangan gizi akan menyebabkan beberapa efek serius seperti kegagalan pertumbuhan fisik serta tidak optimalnya perkembangan dan kecerdasan, akibat lain adalah terjadinnya penurunan produktivitas, menurunnya daya tahan tubuh terhadap penyakit yang akan meningkatkan risiko kesakitan dan kematian.

\section{Hubungan Pengetahuan lbu tentang Pertumbuhan dengan Status Gizi}

Hasil analisis hubungan pengetahuan ibu tentang pertumbuhan dengan status gizi anak usia 0-59 bulan di wilayah kerja Puskesmas Banguntal Bantul Yogyakarta dapat dilihat pada Tabel 4.

Berdasarkan Tabel 4 sebagian besar responden pengetahuan ibu tentang pertumbuhannya baik dan status gizi anak usia 0-59 bulan juga baik sebanyak 49 responden $(55,1 \%)$. Berdasarkan hasil perhitungan diperoleh $p$-value $=0,000<0,05$. Hal ini berarti terdapat hubungan yang signifikan antara pengetahuan ibu tentang pertumbuhan dengan status gizi anak usia 0-59 bulan. Keeratan hubungan antara pengetahuan ibu tentang pertumbuhan dengan status gizi anak usia 0-59 bulan cukup kuat $(r=0,693)$. Hasil penelitian sejalan dengan peneitian Kurniawati yang menyatakan ada hubungan antara tingkat pengetahuan ibu tentang gizi dengan status gizi balita(14).

Kudarti juga menyatakan hal yang serupa bahwa ada hubungan antara pengetahuan ibu tentang gizi dengan status gizi pada balita dengan nilai 0,0001 yang berarti lebih kecil dari $\alpha=0,05(15)$.

Pemantauan pertumbuhan dan status gizi balita merupakan hal penting yang harus diketahui oleh setiap orang tua, dibutuhkan tingkat pemahaman yang lebih tinggi tentang pertumbuhan dan status gizi balita. Dengan latar belakang pendidikan yang tinggi maka akan semakin mudah bagi seorang ibu menerima informasi mengenai pertumbuhan dan status gizi balita(10).

Pendidikan pada dasarnya merupakan salah satu usaha untuk mengembangkan kepribadian dan kemampuan di dalam dan diluar sekolah dan berlangsung seumur hidup. Pendidikan mempengaruhi proses belajar, makin tinggi pendidikan seseorang makin mudah orang tersebut untuk menerima informasi. Semakin banyak informasi yang masuk, semakin banyak pula pengetahuan seseorang yang didapat tentang kesehatan. Pengetahuan sangat erat kaitannya dengan pendidikan. Seseorang diharapkan dengan pendidikan yang tinggi, maka orang tersebut semakin bertambah pula pengetahuannya terhadap status gizi(13).

Hasil penelitian menunjukkan pengetahuan ibu berhubungan signifikan dengan status gizi balita dengan $p=0,001$, semakin baik pengetahuan ibu maka akan semakin baik status gizi anak balitanya. Status gizi balita dapat diketahui dengan cara mengukur berat badan dan tinggi badan(7).

\section{SIMPULAN DAN SARAN}

Berdasarkan hasil dan bahasan dapat disimpulkan mayoritas responden berusia 20-35 tahun dengan tingkat pendidikan SMA, mayoritas ibu tidak bekerja dan paritas ibu 2. Pengetahuan ibu tentang pertumbuhan anak usia 0-59 bulan di Desa Jambidan Wilayah Kerja Puskesmas Banguntapan I Bantul Yogyakarta mayoritas kategori baik, status gizi anak usia 0-59 bulan dalam kategori normal sebesar $70,8 \%$, gemuk $18,0 \%$, kurus $3,4 \%$, dan sangat kurus $3,4 \%$. Ada hubungan tingkat pengetahuan ibu tentang pertumbuhan dengan status gizi anak usia 0-59 bulan di Desa Jambidan Wilayah Kerja Puskesmas Banguntapan I Bantul Yogyakarta Tahun 2013.

Hasil penelitian ini dapat dijadikan sebagai sarana untuk meningkatkan pemahaman serta menambah wawasan pengetahuan dalam ilmu keperawatan anak, diharapkan agar perawat Puskesmas Baguntapan I Bantul Yogyakarta mampu memberikan asuhan keperawatan terkait pengetahuan ibu terhadap pertumbuhan dan status gizi balita, dapat menjadi acuan bagi para kader posyandu dalam meningkatakan pengetahuan tentang gizi dengan cara memberikan penyuluhan dan informasi terkait dengan KADARZI (keluarga

Tabel 4. Hubungan Pengetahuan Ibu tentang Pertumbuhan dengan Status Gizi Anak Usia 0-59 Bulan di Wilayah Kerja Puskesmas Banguntal Bantul Yogyakarta, Juli 2013

\begin{tabular}{|c|c|c|c|c|c|c|c|c|c|c|c|}
\hline \multirow{3}{*}{ Pengetahuan } & \multicolumn{8}{|c|}{$\begin{array}{l}\text { Status Gizi } \\
\end{array}$} & \multirow{3}{*}{ Total } & \multirow{3}{*}{$p$-value } & \multirow{3}{*}{$\mathbf{r}$} \\
\hline & \multicolumn{2}{|c|}{ Normal } & \multicolumn{2}{|c|}{ Gemuk } & \multicolumn{2}{|c|}{ Kurus } & \multicolumn{2}{|c|}{ Sangat Kurus } & & & \\
\hline & $f$ & $\%$ & $f$ & $\%$ & $f$ & $\%$ & $f$ & $\%$ & & & \\
\hline Baik & 49 & 55,1 & 0 & 0,0 & 0 & 0,0 & 0 & 0,0 & 55,1 & 0,000 & 0,693 \\
\hline Cukup & 18 & 20,2 & 16 & 18,0 & 3 & 3,4 & 0 & 0,0 & 41,6 & & \\
\hline Kurang & 0 & 0,0 & 0 & 0,0 & 0 & 0,0 & 3 & 3,4 & 3,4 & & \\
\hline Total & 67 & 75,3 & 16 & 22,5 & 3 & 3,4 & 3 & 3,4 & 100,0 & & \\
\hline
\end{tabular}


sadar gizi), sebagai sumber referensi terkait dengan masalah status gizi anak, serta perlu diteliti lebih lanjut terkait dengan variabel perancu lain yang dapat mempengaruhi status gizi, sebagai bahan aplikasi nyata serta sumber pustaka bagi ilmu keperawatan anak terkait dengan masalah status gizi anak.

\section{RUJUKAN}

1. Bappenas. Millennium Development Goals [Internet]. 2008 [cited 2012 Oct 30]. Available from: http://www.undp.or.id/lets-speak-out-orMDGs/ID

2. WHO. Eradicate Extreme Poverty and Hunger [Internet]. MDG1. 2010 [cited 2012 Oct 21]. Available from: http://www.who.int/tpics/

3. Departemen Kesehatan RI. Riset Kesehatan Dasar [Internet]. 2010 [cited 2012 Oct 16]. Available from: http://www.ppid.depkes.go.id/ documentask

4. Dinkes Bantul. Narasi Profil [Internet]. 2012 [cited 2012 Nov 17]. Available from: http://dinkes. bantulkab.go.id/documents/20120725-narasiprofil-2012

5. Wiryo H. Peningkatan Gizi Bayi, Anak, Ibu Hamil, dan Menyusui dengan Bahan Makanan Lokal. Jakarta: Sugeng Seto; 2002.

6. Riyadi S, Ratnaningsih I. Tumbang, Cara Praktis Orang Tua untuk Memantau Pertumbuhan dan Perkembangan Anak. Yogyakarta: Pustaka Pelajar; 2012.

7. Supariasa IDN, Bakri B, Fajar I. Penilaian Status Gizi. Jakarta: EGC; 2002.
8. Yupi Supartini. Konsep Dasar Keperawatan Anak. Jakarta: EGC; 2004.

9. Notoatmodjo S. Promosi Kesehatan dan IImu Prilaku. Jakarta: Rineka Cipta; 2007.

10. Erfandi. Pengetahuan dan Faktor-Faktor yang Mempengaruhi [Internet]. 2009 [cited 2012 Oct 23]. Available from: http://forbetterhealth. wordpress.com

11. Melindacare. Kebutuhan Gizi Balita Balita: Hal Utama dalam Pertumbuhan Buah Hati [Internet]. 2011 [cited 2012 Oct 25]. Available from: http:// melindahospital.com

12. Ichlas WON. Hubungan Tingkat Pengetahuan Ibu tentang Pemberian Asupan Gizi dengan Berat Badan Balita di Posyandu Pundung Nogotirto Gamping II Sleman Yogyakarta. Yogyakarta; 2006.

13. Kurniawati FE. Hubungan Tingkat Pengetahuan Ibu tentang Pemberian Makanan Tambahan dengan Status Gizi Anak Bawah Tiga Tahun (Batita) di Desa Jangkaran, Temon, Kulon Progo. Yogyakarta; 2007.

14. Erni Kurniawati. Hubungan Tingkat Pengetahuan Ibu tentang Gizi dengan Status Gizi Balita di Kelurahan Baledono, Kecamatan Purworejo. J Komun Kesehat [Internet]. 2012;3(2):1-8. Available from: http://e-journal.akbid-purworejo. ac.id/index.php/jkk5/article/view/70

15. Kudarti. Hubungan Tingkat Pengetahuan Ibu Tentang Gizi dengan Status Gizi pada Balita di Desa Papringan Kecamatan Kaliwungu Kabupaten Kudus. J Kebidanan dan Kesehat. 2011;1(1):1-7. 